\title{
Deteksi Sinyal Otot Manusia pada Android Menggunakan Sensor Elektromiografi Berbasis Miktrokontroler Arduino UNO
}

\author{
${ }^{1}$ Tyle Yan H.H Lukar*), 1Florentinus Budi Setiawan \\ ${ }^{1}$ Program studi Teknik Elektro, Fakultas Teknik, Universitas Katolik Soegijapranata \\ Semarang, Indonesia \\ tyle.yan97@gmail.com*)
}

\begin{abstract}
Abstrak
Saat ini perkembangan dunia medis sudah sangat maju, diantaranya dalam bidang Biomedis. Pada bidang tersebut terdapat alat sensor Elektromiografi yang berfungsi untuk mendeteksi sinyal otot pada manusia sehingga memudahkan kita dalam mengukur sinyal otot pada manusia. Sinyal Elektromiografi mempunyai amplituda yang sangat kecil maka dibutuhkan suatu komponen tambahan yaitu elektroda gel, sebagai media untuk mendeteksi sinyal otot tersebut. Pada kesempatan ini penulis membuat alat untuk mendeteksi sinyal otot tubuh manusia menggunakan hasil output sinyal Elektromiografi. Hasil sinyal tersebut dikuatkan oleh IC Op-Amp AD620 sebanyak 500 kali dan komparator dalam mode Inverting serta Buffer. Setelah itu diinputkan ke Mikrokontroler Arduino, yang terbagi menjadi dua hasil output yaitu menampilkan hasil pengukuran tersebut ke LCD dan Bluetooth HC-05 yang sudah terkoneksikan dengan smartphone android, sehingga hasil tersebut dapat muncul pada aplikasi smartphone android. Aplikasi yang digunakan untuk memunculkan hasil keluaran sinyal otot pada smartphone yaitu Bluetooth Terminal HC-05.
\end{abstract}

Kata Kunci: elektroda, elektromiografi,amplifier, mikrokontroler arduino, bluetooth hc-05, smartphone android.

\section{Pendahuluan}

Dalam melakukan kegiatan sehari-hari seseorang menggunakan banyak otot yang ada dalam tubuh. Bila sering beraktivitas menggunakan otot yang berlebih untuk bekerja keras khususnya otot pada tangan, perut, dan leher biasanya akan mengalami kram, sakit pinggang, keseleo, terkilir, dan masih banyak lagi. Untuk mendeteksi otot-otot tersebut maka dibutuhkan sensor alat yang bernama Elektromigrafi. Pada dasarnya semua titik otot pada manusia dapat mengeluarkan sinyal elektrik yang dapat difungsikan untuk mengetahui ukuran otot.

Elektromiografi digunakan untuk mengukur aktivitas listrik yang dihasilkan oleh pergerakan zat $\mathrm{Na}^{+}$dan $\mathrm{K}^{+}$didalam jaringan otot tubuh [1]. Agar terjadi sinyal tegangan pada otot manusia maka dibutuhkan elektroda. Proses terjadinya tegangan dibagi menjadi tiga yaitu Polarisasi (otot ditegangkan), Depolarisasi (otot dilemaskan), dan Repolarisasi (fase istirahat)[2]. Sinyal EMG terdiri oleh tegangan dari MUAP[3], sehingga saat melakukan kontraksi pada otot, maka akan mengalami perubahan masa otot sehingga menimbulkan suatu gelombang yang disebut MUAP (Motor Unit Action Potential). Beda potensial saat kontraksi otot ini akan diukur menggunakan sensor EMG (Electromyograph), dengan memasangkan elektroda ke bagian permukaan kulit otot yang akan diukur dilakukan penguatan sebesar 500x dengan menggunakan AD620 dan komparator dual op-amp menggunakan TL062 dengan mode Inverting dan Buffer. Agar sinyal tegangan dapat terbaca pada rangkaian Low Pass Filter dengan envelope detector untuk mendapatkan hasil rata-rata sinyal otot yang dikeluarkan menjadi tegangan DC[2]. Sinyal output tersebut masuk ke mikrokontroler arduino untuk mengirimkan data digital dan ditampilkan pada LCD serta Bluetooth HC-05 yang telah terhubung dengan pin RX-TX pada Arduino. Bluetooth HC-05 harus sudah terkoneksi pada Bluetooth android sehingga pada aplikasi Bluetooth Terminal HC-05 di android akan menerima data yang dikirim melalui Bluetooth $\mathrm{HC}-05$.

Berikut blok diagram dari perancangan sistem alat tersebut.

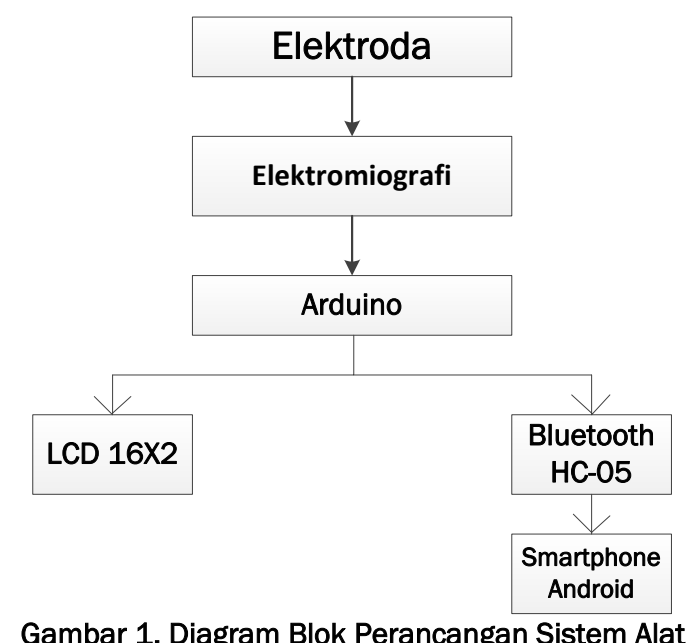




\section{Studi Pustaka}

\subsection{Elektroda}

Merupakan alat sebagai penghubung yang bersifat kimiawi antara permukaan kulit dan bagian metal dari elektroda. Jenis yang digunakan dalam perancangan system ini yaitu menggunakan elektroda jenis gel. Adanya reaksi oksidatif dan reduktif pada permukaan metal dan gel tersebut yang membuat pengukuran pada sinyal otot dapat akurat karena noise yang masuk jauh lebih sedikit[2].

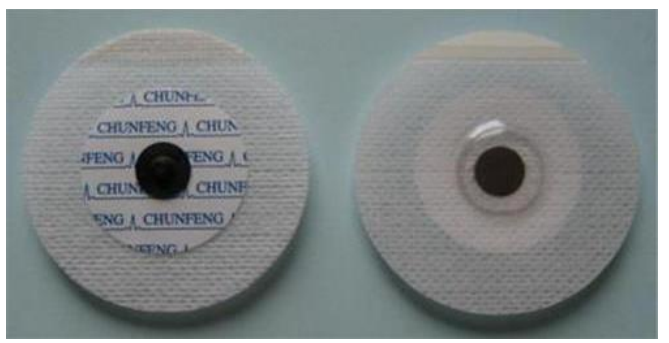

Gambar 2. Elektrode Perak Klorida dilapisi Gel

\subsection{Elektromiografi (EMG)}

Elektromiografi merupakan suatu teknik untuk mengevaluasi dan rekaman aktivitas listrik pada tegangan otot. Untuk menghasilkan suatu rekaman aktivitas listrik biasanya disebut Elektromiogram. Cara kerja EMG dengan mendeteksi potensial listrik yang dihasilkan sel-sel otot saat neurologis atau sel-sel elektrik diaktifkan, sehingga sinyal tersebut dapat dianalisis untuk mendeteksi kelainan medis pada gerakan manusia[2].

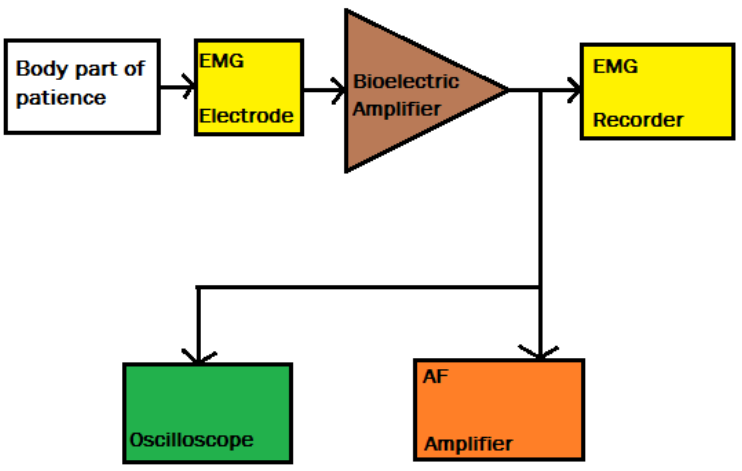

Gambar 3. Blok Diagram Elektromiografi

\section{Rancangan Peralatan}

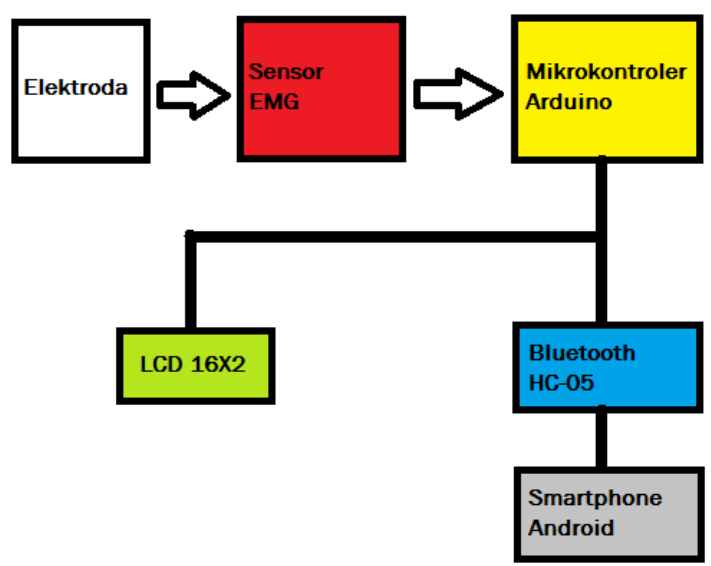

Gambar 4. Rancangan Alat

\subsection{Rangkaian Analog}

Pada rangkaian EMG yang dibuat ini, sensor EMG berfungsi sebagai rangkaian analog. Rangkaian ini terdiri dari tiga komponen Op-Amp, Op-Amp pertama yang digunakan yaitu IC AD620, karena memiliki fungsi dari penguat instrumentasi sendiri dalam menguatkan sinyal otot dari EMG. Op-Amp kedua ialah dual Op-Amp yang diaplikasikan pada mode Inverting dan Buffer serta penyearah setengah gelombang. Untuk TL062 dipasang pada mode Inverting sehingga mempermudah pengaturan sinyal keluaran amplituda yang dihasilkan dari penguatan masukan. Op-Amp ketiga dimasukkan sinyal ke Buffer Amplifier yang diberi diode dan Envelope Detector pada keluarannya[2]. Tujuan dari proses penyearahan dan pemfilteran agar merata-rata sinyal otot yang telah dikuatkan menjadi sinyal DC sehingga dapat dibaca oleh ADC mikrokontroler Arduino Uno.

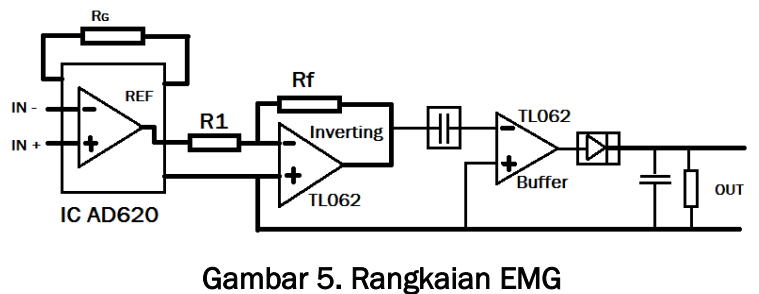

\subsubsection{IC AD 620}

IC AD620 dipilih karena didasari dari pengaplikasian dalam datasheet produk tersebut serta sangat efisien karena hanya membutuhkan satu buah resistor dalam menentukan nilai penguatnya[2][4]. Berikut rumus untuk menentukan nilai resistor yang akan digunakan dan penguat yang dihasilkan sebagai berikut : 


$$
R_{G}=\frac{49.4 k \Omega}{G-1}
$$

Keterangan :

$\mathrm{RG}_{\mathrm{G}} \quad$ : Nilai resistor yang akan digunakan

G : Nilai penguatan yang diinginkan

Sehingga nilai penguatan dalam tugas akhir ini adalah 500 kali, serta resistor yang digunakan adalah $100 \Omega$.

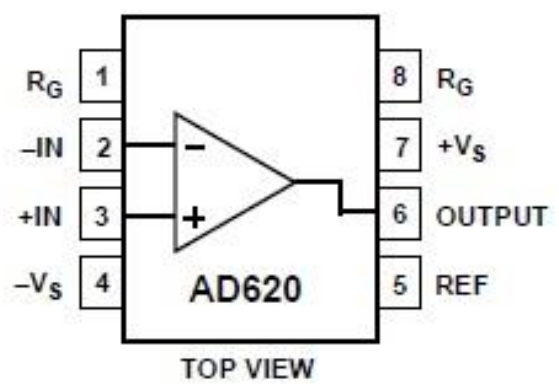

Gambar 6. Pinout IC AD620

\subsubsection{Dual Op-Amp TL062}

IC TL062 dipilih karena didasari atas tingginya impedansi masukan dari Op-Amp. IC ini digunakan dalam mode Inverting dan Buffer, sehingga menguatkan sinyal yang dihasilkan AD620[2].

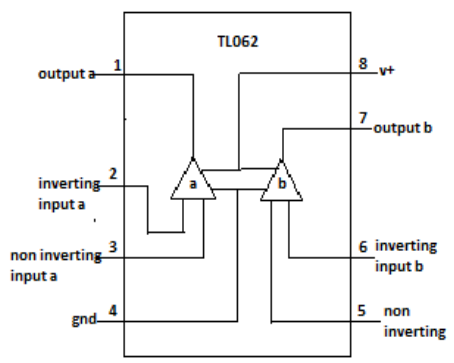

Gambar 7. IC TLO62

\subsubsection{Envelope Detector}

Envelope Detector merupakan rangkaian yang terdiri dari sebuah dioda, sebuah resistor dan sebuah kapasitor. Dioda sebagai menyearahkan setengah gelombang, lalu resistor dan kapasitor berfungsi sebagai Low Pass Filter[2].

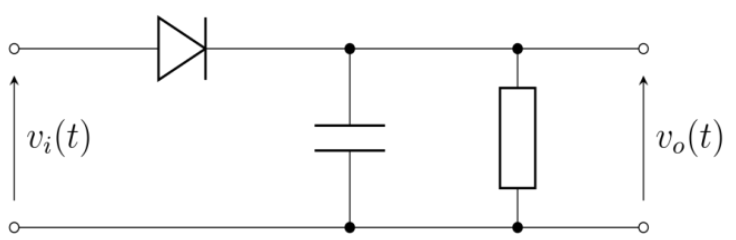

Gambar 8. Rangkaian Envelope Detector

\subsection{Rangkaian Digital}

Rangkaian digital ini menggunakan mikrokontroler Arduino Uno yang terdapat ATMega328. Pada konfigurasinya memiliki 14 pin input/output dimana 6 pin digunakan sebagai output PWM, 6 input analog, $16 \mathrm{MHz}$ crystal osilator, koneksi USB, jack power, ICSP header dan tombol reset. Board Arduino menyupport dua sumber masukkan yaitu kabel USB dan adaptor AC ke DC 7-12volt[6].

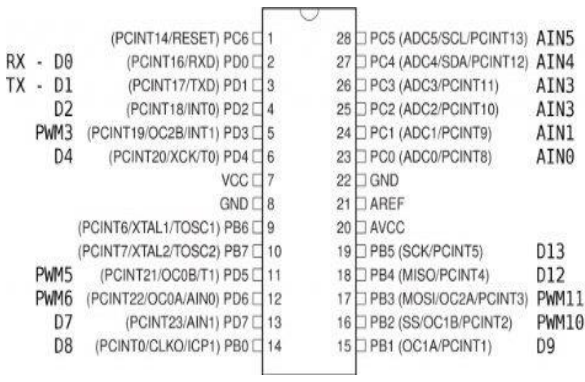

Gambar 9. Konfigurasi Pinout Arduino Uno

\subsection{Bluetooth $\mathrm{HC}-05$}

Merupakan alat komunikasi wireless yang bekerja pada frekuensi radio $2.4 \mathrm{GHz}$ agar dapat mempermudah koneksi dengan laptop dan handphone. Modul Bluetooth HC-05 terdapat 6 pin konektor, setiap pin konektor mempunyai fungsi yang berbeda-beda. Modul Bluetooth HC-05 di supply tegangan sebesar 3.6V - 6V[8].
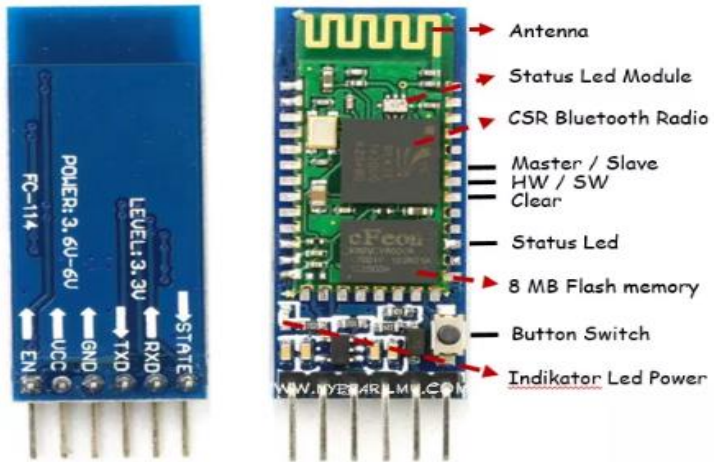

Gambar 10. Modul Bluetooth HC-05

\subsection{Smartphone Android}

Smartphone android merupakan sistem operasi perangkat lunak, bertugas untuk melakukan kontrol dan memanajemen perangkat keras serta beroperasi pada dasar sistem termasuk menjalankan software aplikasi pada smartphone. Pada pengujian alat ini smartphone digunakan untuk menjadi salah satu output dari keluaran alat ini. Agar dapat mengirimkan hasil data keluaran tersebut maka Bluetooth pada 
Seminar Nasional Instrumentasi, Kontrol dan Otomasi (SNIKO) 2018 Bandung, Indonesia, 10-11 Desember 2018

smartphone harus terhubung dengan Bluetooth hc-05.

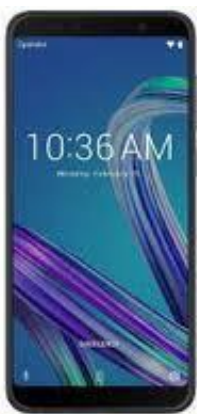

Gambar 11. Contoh Smartphone

\subsection{Aplikasi Bluetooth Terminal HC-05}

Ini adalah aplikasi terakhir yang digunakan pada android untuk menerima data dari Bluetooth HC-05. Aplikasi Bluetooth Terminal HC-05 adalah salah satu aplikasi yang dapat menghubungkan android dengan alat mikrokontroler sinyal otot yang sudah menggunakan komunikasi Bluetooth secara serial. Sehingga data yang diterima dapat dimunculkan dalam aplikasi android yang bernama Bluetooth Terminal HC-05 tersebut.

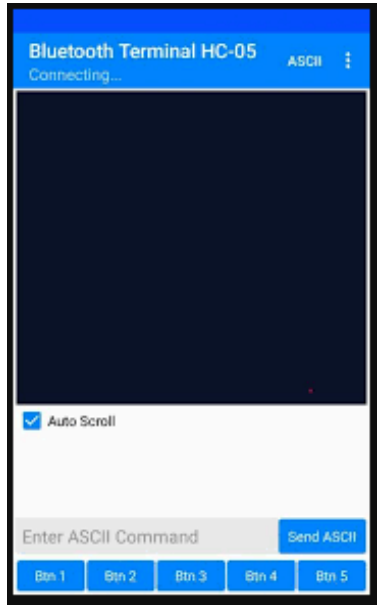

Gambar 12. Tampilan Aplikasi Bluetooth Terminal HC-05

\subsection{Algoritma program}

Pada bagian ini dijelaskan secara singkat mengenai algoritma yang dipakai dalam pembuatan program yang dipakai untuk menampilkan hasil keluaran sinyal otot dari alat EMG ke Bluetooth HC-05.

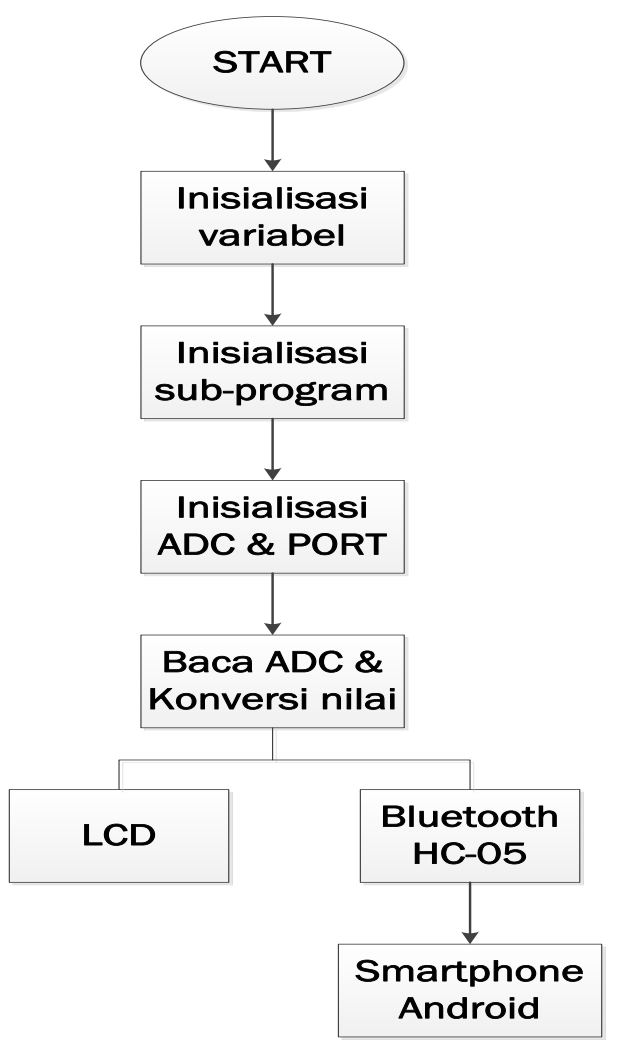

Gambar 13. Diagram Algoritma Program

\section{Hasil Pengujian}

Pada dibawah ini adalah hasil pengujian alat, dimana terdapat hasil sinyal dari tiga titik otot tersebut pada sinyal osiloskop dan hasil tegangan keluaran otot pada android.

Hasil pengujian terhadap tiga titik otot orang pertama atau dikategorikan mempunyai badan yang kurus.

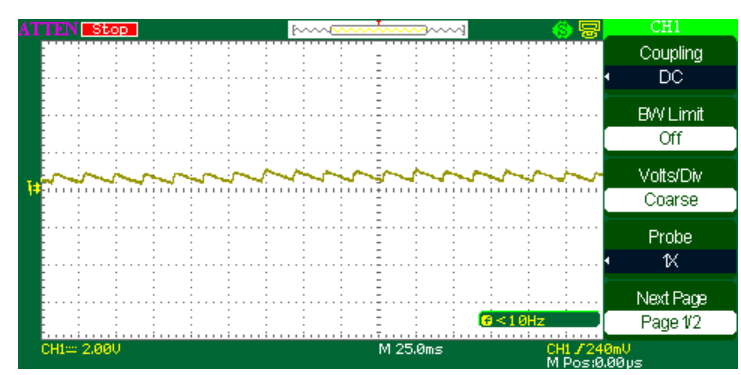

Gambar 14. Hasil Sinyal Otot Platysma saat Relaksasi 
Seminar Nasional Instrumentasi, Kontrol dan Otomasi (SNIKO) 2018 Bandung, Indonesia, 10-11 Desember 2018

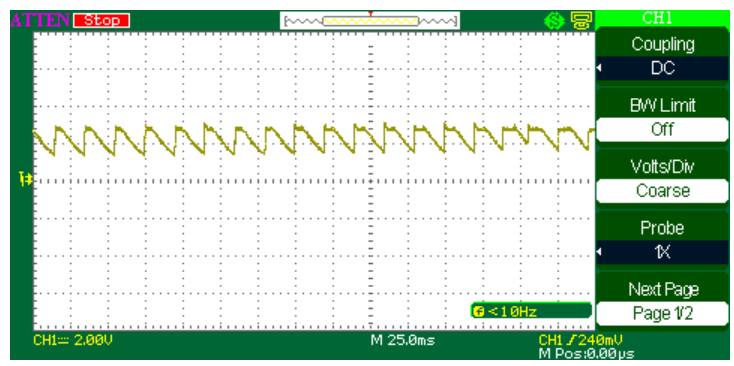

Gambar 15. Hasil Sinyal Otot Platysma saat Kontraksi

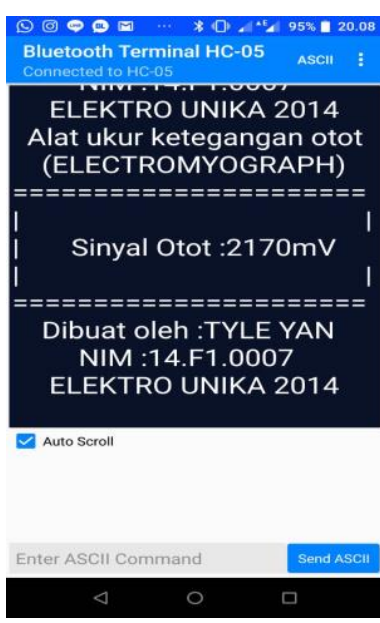

Gambar 16. Hasil Pengukuran dari Smartphone saat Otot Platysma Kontraksi

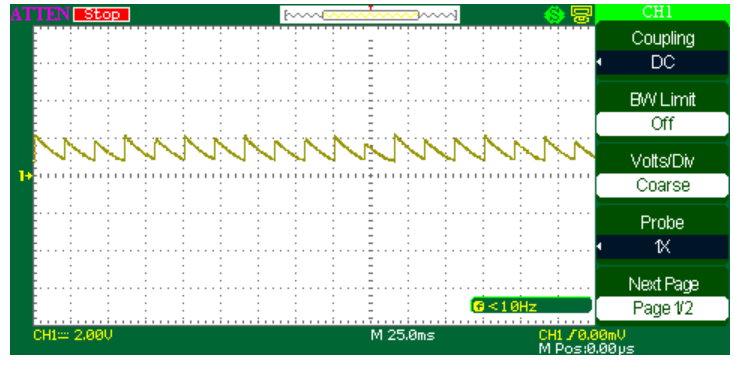

Gambar 17. Hasil Sinyal Otot Tangan Bisep saat Relaksasi

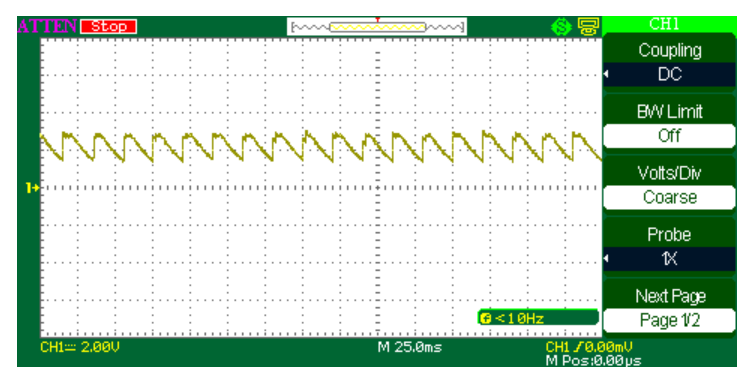

Gambar 18. Hasil Sinyal Otot Tangan Bisep saat Kontraksi
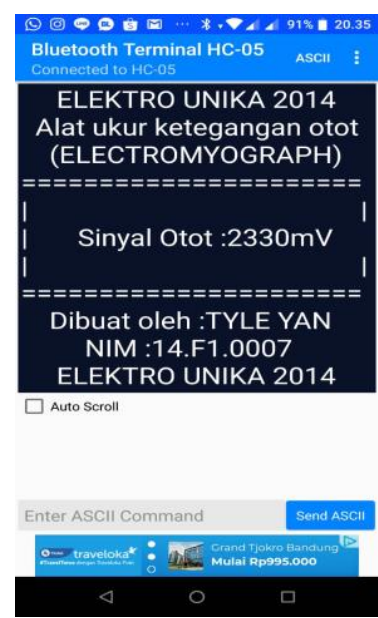

Gambar 19. Hasil Pengukuran dari Smartphone saat Otot Tangan Bisep Kontraksi

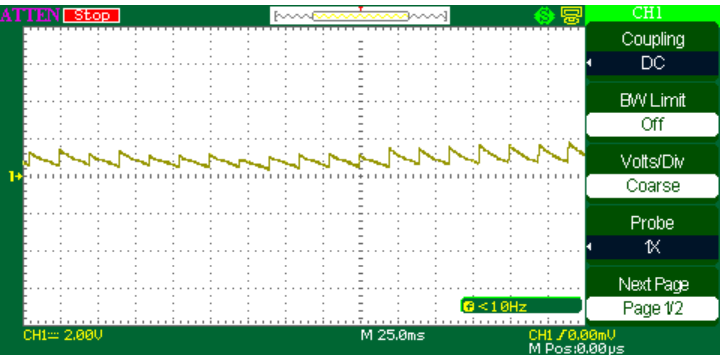

Gambar 20. Hasil Sinyal Otot Perut saat Relaksasi

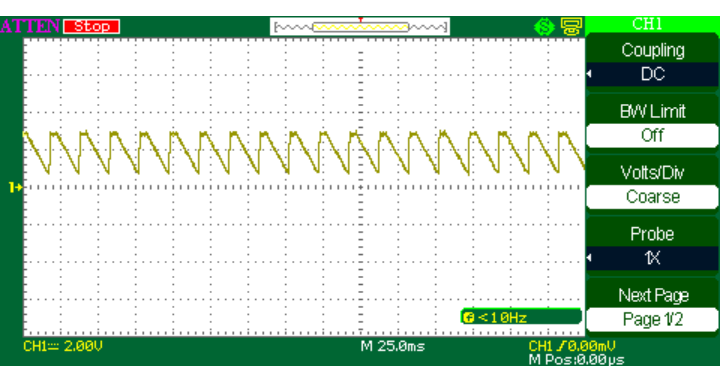

Gambar 21. Hasil Sinyal Otot Perut saat Kontraksi

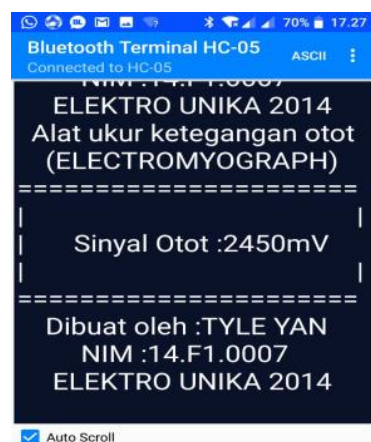

auto Scroll

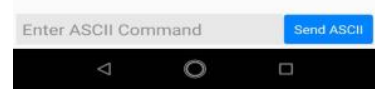

Gambar 22. Hasil Pengukuran dari Smartphone saat Otot Perut Kontraksi 
Hasil pengujian terhadap tiga titik otot orang kedua atau dikategorikan mempunyai berat badan yang normal.

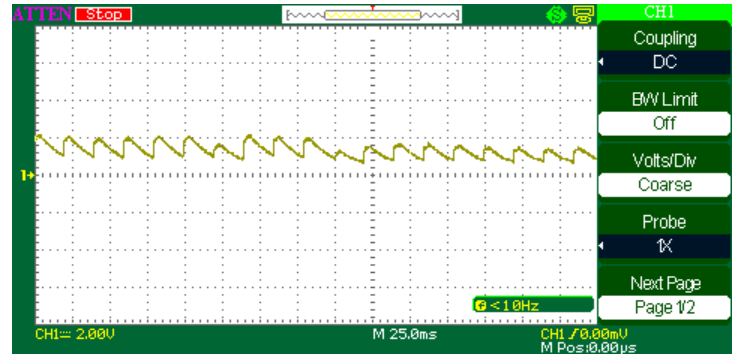

Gambar 23. Hasil Sinyal Otot Platysma saat Relaksasi

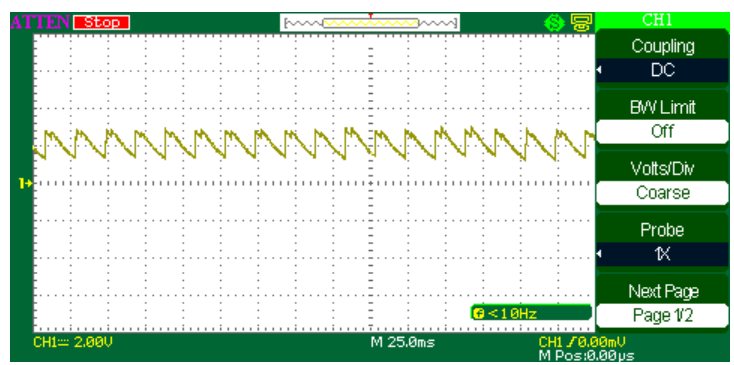

Gambar 24. Hasil Sinyal Otot Platysma saat Kontraksi

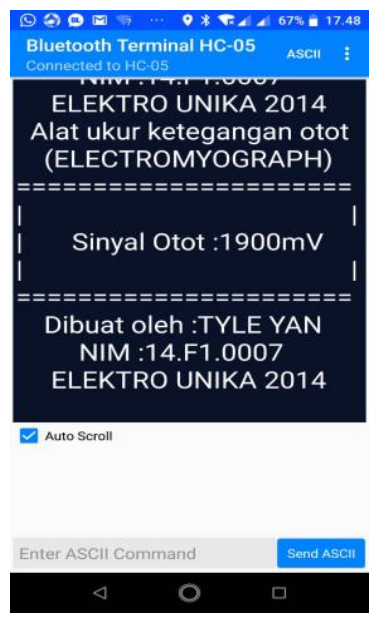

Gambar 25. Hasil Pengukuran dari Smartphone saat Otot Platysma Kontraksi

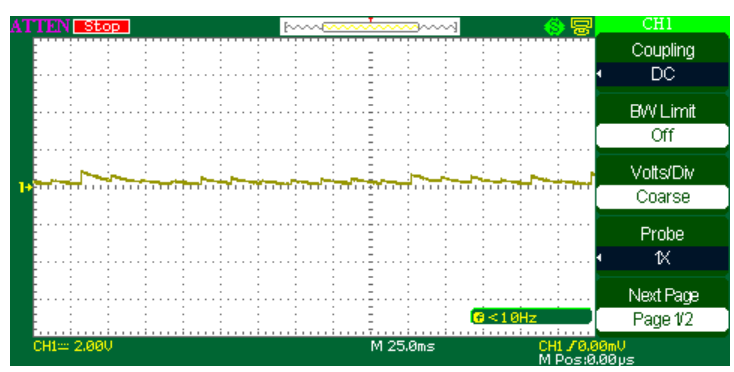

Gambar 26. Hasil Sinyal Otot Tangan Bisep saat Relaksasi

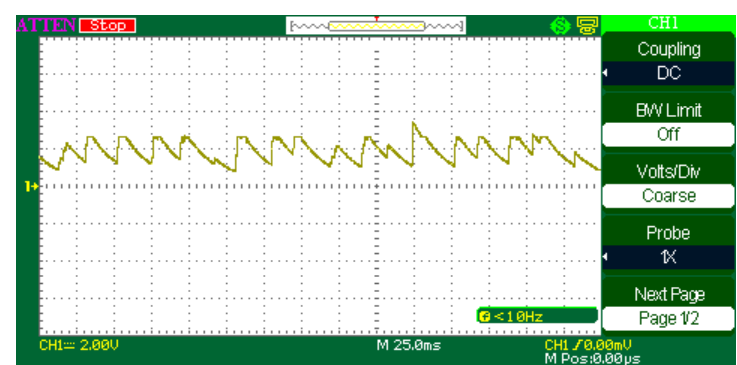

Gambar 27. Hasil Sinyal Otot Tangan Bisep saat Kontraksi
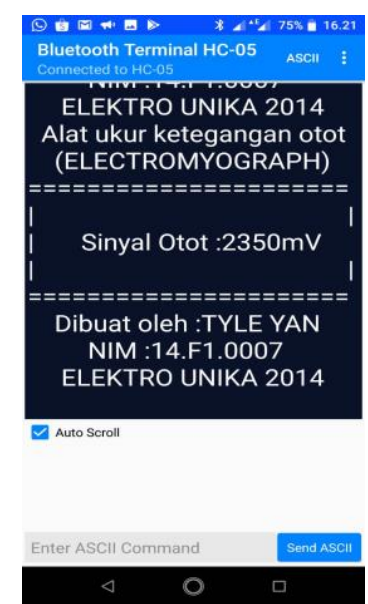

Gambar 28. Hasil Pengukuran dari Smartphone saat Otot Tangan Bisep Kontraksi

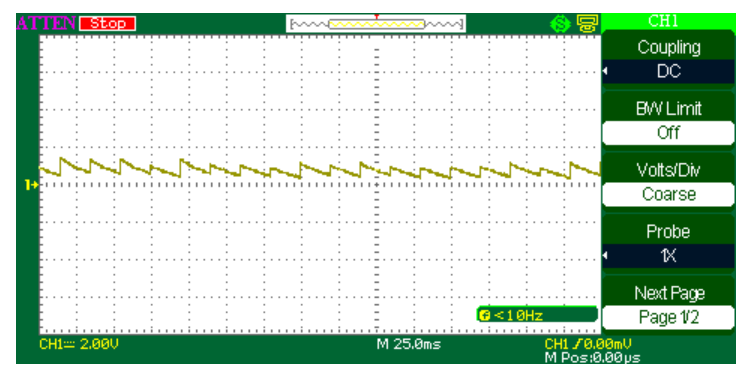

Gambar 29. Hasil Sinyal Otot Perut saat Relaksasi

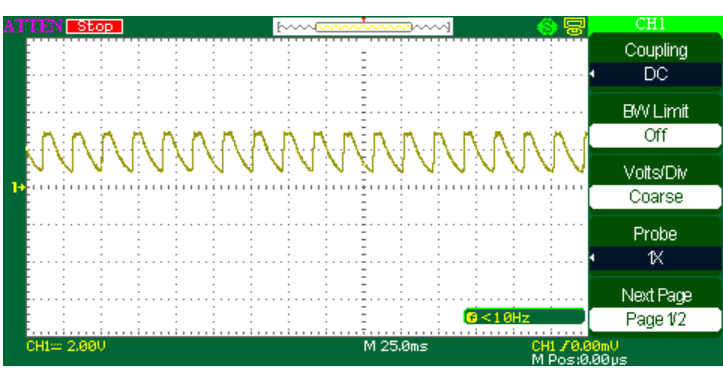

Gambar 30. Hasil Sinyal Otot Perut saat Kontraksi 
Seminar Nasional Instrumentasi, Kontrol dan Otomasi (SNIKO) 2018 Bandung, Indonesia, 10-11 Desember 2018
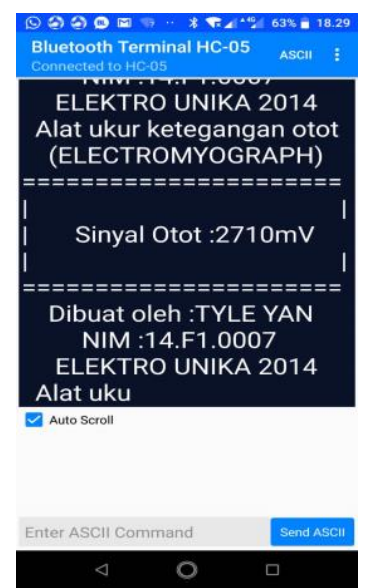

Gambar 31. Hasil Pengukuran dari Smartphone saat Otot Perut Kontraksi

Hasil pengujian terhadap tiga titik otot orang ketiga atau dikategorikan mempunyai berat badan yang lebih.

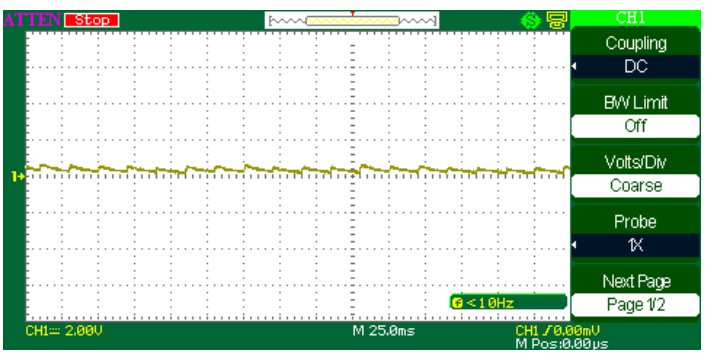

Gambar 32. Hasil Sinyal Otot Platysma saat Relaksasi

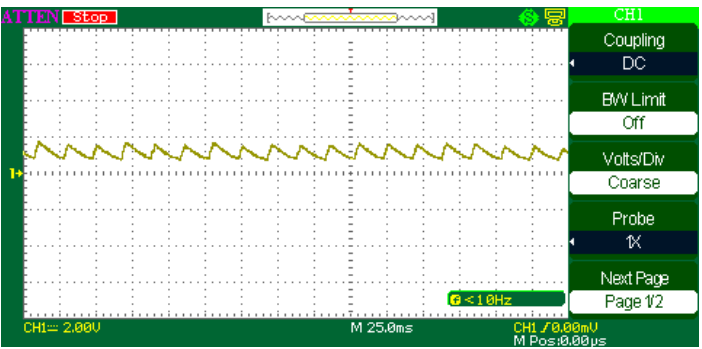

Gambar 33. Hasil Sinyal Otot Platysma saat Kontraksi
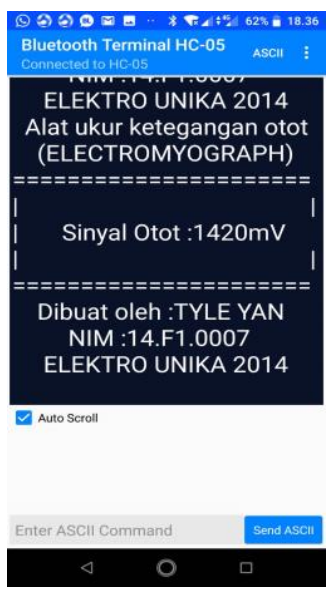

Gambar 34. Hasil Pengukuran dari Smartphone saat Otot Platysma Kontraksi

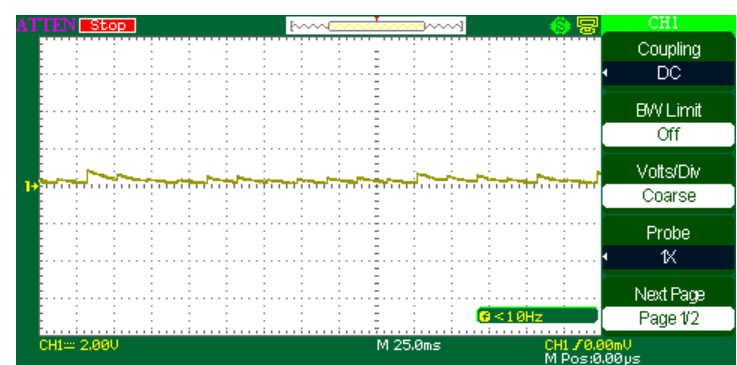

Gambar 35. Hasil Sinyal Otot Tangan Bisep saat Relaksasi

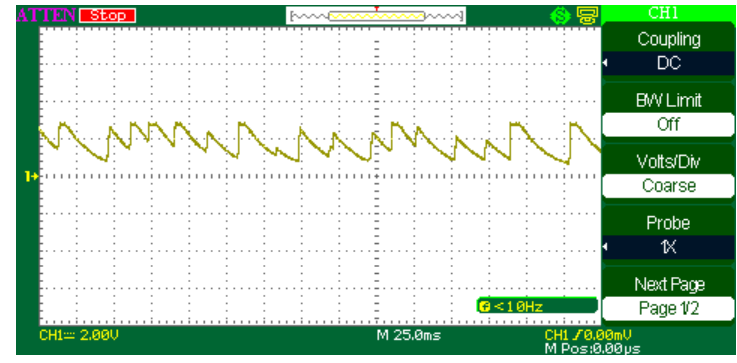

Gambar 36. Hasil Sinyal Otot Tangan Bisep saat Kontraksi

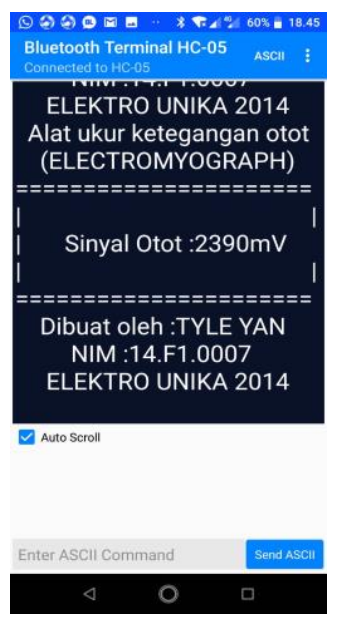

Gambar 37. Hasil Pengukuran dari Smartphone saat Otot Tangan Bisep Kontraksi

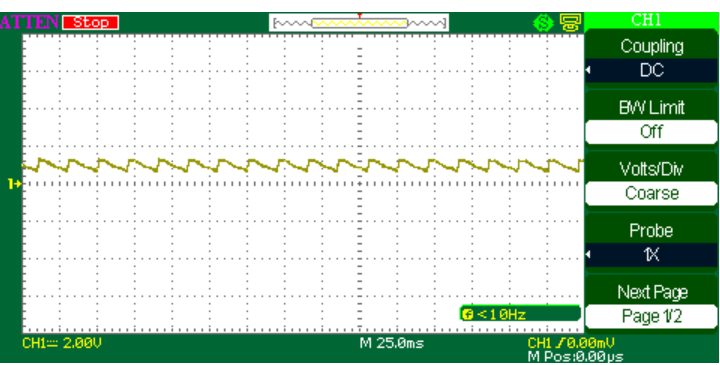

Gambar 38. Hasil Sinyal Otot Perut saat Relaksasi 


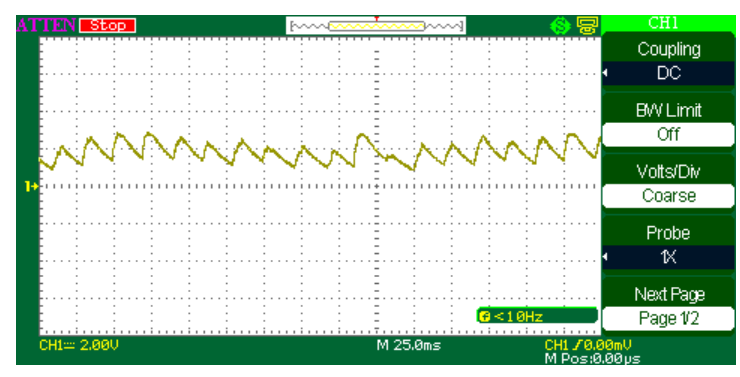

Gambar 39. Hasil Sinyal Otot Perut saat Kontraksi

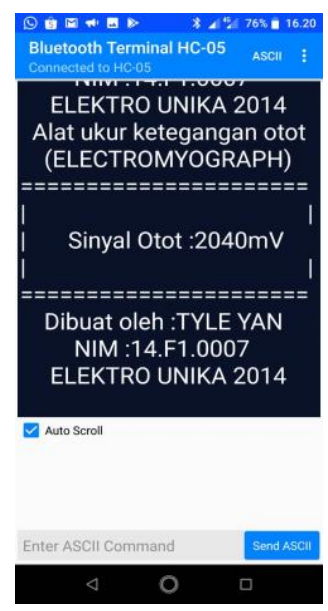

Gambar 40. Hasil Pengukuran dari Smartphone saat Otot Perut Kontraksi

\section{Kesimpulan}

Pada pengujian alat ini, penulis melakukan pengukuran pada tiga titik otot berbeda dengan kriteria orang yang berbeda. Ketiga titik otot tersebut terdiri dari otot platysma, otot tangan bisep dan otot perut di setiap orangnya, dimana hasil pengukuran tegangan sinyal otot akan berbeda-beda. Dari hasil pengukuran otot platysma paling kecil sebesar $1420 \mathrm{mV}$ dan paling besar $2170 \mathrm{mV}$. Hasil pengukuran otot tangan bisep paling kecil yaitu $2330 \mathrm{mV}$ dan paling besar yaitu $2390 \mathrm{mV}$. Hasil pengukuran otot perut paling kecil yaitu 2040mV dan paling besar yaitu $2710 \mathrm{mV}$.

\section{Daftar Pustaka}

[1] Kevin Eka Pramudita, F Budi Setiawan, Siswanto, "Interface and display of Electromyography signal wireless measurements", International Conference on Information Technology, Computer and Electrical Engineering (ICITACEE), 2014.

[2] Ricky Fajar Adiputra, Florentinus Budi Setiawan, "ROBOT ARM CONTROLLED BY MUSCLE TENSION BASED ON ELECTROMYOGRAPHY AND PIC18F4550", Int. Conf. on Information Tech., Computer and Electrical Engineering (ICITACEE), Oct 19-21st, 2016.

[3] Florentinus Budi Setiawan, Siswanto, "Electromyography (EMG) Signal Compression using Sinusoidal Segmental Model", International Conference on Information Technology, Computer and Electrical Engineering (ICITACEE), 2015.

[4] Nasiqin, Imam, Arif Surtono dan Gurum Ahmad Pauzi, "Rancang Bangun Penguat Biopotensial Elektrokardiografi(EKG) Berbasis AD620", JURNAL Teori dan Aplikasi Fisika, 2015.

[5] Konrad,Peter. The ABC of EMG : A Practical Introduction to Kinesiological Electromyography. April 2005.

[6] Arduino datasheet, octopart, 2014.

[7] AD620 datasheet, Analog Device, 2010.

[8] HC-05 datasheet, ITead Studio, 2010.

[9] J. Gotuzzo, S. Vu, S. Dee and K. George, "Electromyography Based Orthotic Arm and Finger Rehabilitation System," 2018 IEEE International Conference on Healthcare Informatics (ICHI), New York City, NY, USA, 2018, pp. 338-339.

[10]Yohanes Oxa Wijaya, Florentinus Budi Setiawan, Siswanto, "Desain dan Implementasi Alat Pengukur Ketegangan Otot", Industrial Research Workshop and National Seminar, 2014.

[11]Florentinus Budi Setiawan, Siswanto, "Multi Channel Electromyography (EMG) Signal Acqiusition using Microcontroller with Rectifier", Int. Conf. on Information Tech., Computer and Electrical Engineering (ICITACEE), Oct 19-21 ${ }^{\text {st }}, 2016$.

[12]Rizki Multajam dan Mada Sanjaya, "DESAIN DAN ANALISIS ELECTROMYOGRAPHY (EMG) SERTA APLIKASINYA DALAM MENDETEKSI SINYAL OTOT", ALHAZEN Journal of Physics, Vol. 2, No. 2, 2016. 